\title{
Growth promotion in farm animals
}

\author{
BY PETER J. BUTTERY AND JANET M. DAWSON \\ Department of Applied Biochemistry and Food Science, University of Nottingham, School of \\ Agriculture, Sutton Bonington, Loughborough, Leics LE12 SRD
}

The use of anabolic steroids has indicated clearly that it is possible to enhance the growth of farm animals, especially ruminants. Enhancement of growth rate normally reduces the cost of producing meat. In recent years the importance of reducing the fat intake of the human population has been fully recognized and methods have been developed to enhance the deposition of lean at the expense of fat, usually by alteration of the animal's endocrine status, for example by the application of beta-agonists. Advances in biotechnology, especially during the last decade, have enabled the scientific community to develop methods to enhance the performance of animals without direct application of hormones or their analogues. However, the application of these scientific achievements is attracting more and more attention from a vocal segment of the public who oppose the use of what they consider to be unnatural methods of food production, and from certain politicians, especially in Europe, who wish to control the production of food so as to reduce surpluses which occur in some of the developed countries of the world. In addition, both the relative abundance of food supplies, at least for the developed world, together with advances in scientific knowledge have increased the rigour with which the safety of food products is judged. The previously described statements combine to make the quest to produce acceptable methods of safely and humanely enhancing the efficiency of meat production from animals a most interesting challenge.

\section{ANABOLIC STEROIDS}

Many studies have reported the efficacy of anabolic agents since Dinusson et al. (1950) first demonstrated that the oestrogenic substance diethyl stilbesterol when implanted into heifers increased growth rate. Since that time a series of implants based on the natural sex steroids has been developed to enhance the growth of animals, especially ruminants. Oestradiol, oestradiol benzoate plus progesterone, and oestradiol benzoate plus testosterone are among the most commonly used preparations of the natural sex steroids used in many parts of the world and have been shown to increase growth rate by $8-15 \%$ and feed conversion efficiency by $5-10 \%$. In addition to these endogenous hormonal implants, several analogues have been developed. The two which received licences in various countries are the testosterone analogue, trenbolone acetate, and zeranol, an oestrogenic substance derived from the fungal metabolite zeralanone. Numerous studies were conducted on the safety of these materials both to the consumer of the meat and to the treated animal. In the European Economic Community (EEC) an expert committee concluded that at least for the natural hormones and compounds which are rapidly metabolized to yield natural hormones, provided they were used according to the officially approved manufacturers' instructions, they presented no hazard especially to the eventual consumer of the meat (Lamming et al. 1987). Among the pieces of evidence available is the comparison between the quantity of an implanted hormone, 
e.g. oestradiol in $250 \mathrm{~g}$ meat and the endogenous daily hormone production in a prepubertal child. A $250 \mathrm{~g}$ steak from a steer treated with oestradiol contains about 0.005 $\mu \mathrm{g}$ oestradiol compared with a child's daily endogenous oestradiol production of $42 \mu \mathrm{g}$. Similar convincing findings are available for testosterone and for progesterone (Heitzman et al. 1984). Despite the scientific evidence the use of all hormone implants to promote growth of animals within the EEC is now banned (directive 85/649 EEC). However, use of anabolic implants remains a permitted practice in animal production in many other countries of the world, e.g. the USA.

Many studies on the mode of action of anabolic steroids have been conducted and some have yielded unexpected observations. For example, treatment of ruminants and rats with the androgenic substance trenbolone acetate enhances the rate of muscle accretion but this is achieved by a small reduction in the rate of muscle protein synthesis and a much larger decrease in the rate of muscle protein catabolism (Vernon \& Buttery, 1978; Sinnett-Smith et al. 1983). Testosterone works by enhancing the rate of both reactions (Martinez et al. 1984). Oestradiol implants are particularly effective in cattle and its mode of action has been suggested to involve the enhancement of endogenous growth hormone secretion. The precise mode of action of trenbolone acetate has yet to be elucidated but, as with oestradiol, part of its effects is likely to be associated with changes in the circulating concentrations of several of the endogenous hormones (Buttery \& Sinnett-Smith, 1982). Hunter \& Vercoe (1987) have recently described an alternative application of trenbolone acetate which exploits its mechanism of action. As this compound reduces the rate of muscle protein turnover and consequently reduces basal energy expenditure, this group of Australian workers were able to reduce the weight loss of cattle fed on very-poor diets. They suggest that trenbolone acetate may enable cattle to withstand better the marked fluctuations in nutrient availability often seen in the tropics and sub-tropics.

It is unlikely that the full extent of the growth-promoting properties of anabolic steroids will be seen unless the animal is adequately fed. For example, studies with silage-fed steers treated with oestradiol demonstrate that a significant growth response is only seen when animals are given supplementary protein (Gill et al. 1987; Newbold et al. 1988). A possible explanation for this comes from the work of Breier et al. (1988a,b), see p. 461. A similar interaction with diet, although judged not to be statistically significant, has been reported for the combined implant of trenbolone acetate plus oestradiol (Galbraith et al. 1983).

\section{GROWTH HORMONE}

The ability to produce bovine growth hormone by recombinant technology has resulted in a detailed investigation of the potential of using exogenously applied growth hormone to enhance growth in farm livestock. Although the response to growth hormone varies, on average an increase in growth rate of $12 \%$ is obtained in cattle but some increases up to $25 \%$ have been reported. This increased growth is usually associated with a reduction in fat and an increase in the lean content of the carcass (Enright, 1989). This repartitioning effect can mask overall effects on growth rate (Pell, 1989).

Growth hormone treatment causes an increased rate of muscle protein synthesis in the muscle (Pell, 1989). Pell et al. (1989) investigated the interaction between diet and response to growth hormone in lambs and were able to show that the reduction in fat 
content is related to the extent to which the control animals are depositing fat, the biggest reductions being seen in animals on a high plane of nutrition. Although some increases in muscle mass are seen in animals on a low plane of nutrition (Peters, 1986) maximal effects will only be seen in animals receiving an adequate protein intake (Enright, 1989). The work of Breier et al. (1988a,b) and of Elsasser et al. (1989) gives some insight into the mechanism of the interaction between plane of nutrition and response to growth hormone. These workers showed that plasma insulin-like growth factor (IGF)-1 concentrations increased more in response to growth hormone when animals were on a high plane of nutrition than when poorly fed. A low plane of nutrition results in a reduction in hepatic growth hormone receptors, thus reducing the extent of IGF-1 release from the liver in response to circulating growth hormone. This dietary influence on the hepatic growth hormone receptor could also explain in part the failure of oestradiol to promote growth in poorly-fed animals.

An interesting development in the use of growth hormone to enhance growth has been the discovery that some monoclonal antibodies to a hormone may enhance rather than inhibit its activity (Holder \& Aston, 1989). The possibility exists, therefore, that treatment of an animal with an antibody to growth hormone may increase lean deposition without the need to give growth hormone exogenously, i.e. the antibody interacting with endogenously produced growth hormone (Holder \& Aston, 1989).

The use of growth hormone to promote lean deposition in ruminants and other farm animals has not been approved to date within the EEC.

\section{GROWTH HORMONE-RELEASING FACTOR (GRF) AND OTHER FACTORS INDUCING GROWTH HORMONE RELEASE}

Treatment with GRF has similar effects to growth hormone treatment so far as can be judged from the experiments that have been reported in the literature (Enright, 1989). GRF is a smaller peptide than growth hormone and this, coupled with its greater potency, should in theory make it more attractive as a growth-promoting agent than growth hormone itself. However, the molecule is highly conserved between species especially in residues 1-27, the active portion of the molecule (Baile \& Buonomo, 1987); thus, it is most likely that any preparation used to enhance animal growth would also be active in humans. One point often made in support of bovine growth hormone as an enhancer of animal growth is its inactivity in humans.

A number of other biologically active peptides have been shown to induce growth hormone release including the opioid peptides (beta-endorphin and the enkephalins) and bombesin (a peptide isolated from the skin of the frogs Bombina bombina and Bombina variegata variegata; Millard, 1989). Thus, the possibility exists that these and related materials may potentially have uses as repartitioning and growth-promoting agents.

\section{SOMATOSTATIN}

Somatostatin is a peptide of fourteen amino acids and its structure is conserved across species. It is synthesized as a ninety-two amino acid prosomatostatin molecule from which six peptides including somatostatin itself and a twenty-eight amino acid form of somatostatin are known to be derived (Patel, 1987). Somatostatin inhibits growth hormone secretion, but in addition it also inhibits the secretion of thyrotropin from the 
pituitary and glucagon and insulin release from the pancreas (Patel, 1987). The concept of autoimmunizing animals against somatostatin to enhance growth hormone release was initially explored in sheep by Spencer et al. (1983). These initial studies reported enhanced growth in autoimmunized animals, but subsequent studies by these and other workers have often yielded equivocal results. Bass et al. (1987) more recently obtained findings which again highlighted the importance of diet in the response to a growthpromoting regimen. Lambs were fed on either a good-quality pellet diet or cut pasture and some animals from each group were autoimmunized against somatostatin. Although plasma growth hormone concentrations were higher in both groups of immunized animals, only the animals fed on the pellets showed an increase in weight gain. Presumably the pasture-fed animals which were on a low plane of nutrition had livers which were partially refractory to growth hormone and consequently IGF-1 release (Breier et al. 1988a). It is interesting to note that the findings of Bass et al. (1987) indicate that in animals showing an enhanced growth that there was some evidence, albeit not judged to be significant, for an enhanced deposition of fat; enhanced growth hormone activity would normally be expected to be associated with an increase in lean content (see p. 460). The possibility that the changes in digesta flow seen on immunization against somatostatin also play a major role in the response of animals needs to be considered further (Fadalla et al. 1985). Although autoimmunization against somatostatin does not seem to be a viable method of growth promotion, the use of the immune response to promote growth may be more acceptable to the legislation and the general public than direct application of hormones.

\section{BETA-AGONISTS}

To date numerous reports have shown that a variety of substances with selective binding to the beta-2-adrenergic receptor when included in the diet of mammals reduce body fat and increase lean. The response in chickens is smaller than that seen in mammals but may also be of commercial significance (Hanrahan, 1987). The mode of action of these materials is not fully understood. The reduction in lipid content of the carcass is probably largely due to an increased rate of lipolysis since routinely an increase in plasma-free fatty acids is observed following treatment (e.g., Mersmann et al. 1989). Some in vitro studies have suggested that the main influence of beta-agonist treatment is a reduction in lipogenesis (e.g. Coleman et al. 1988). Whether this effect also occurs in vivo is unknown. There is also debate over the influence of beta-agonists on muscle protein metabolism. Some reports have suggested an increase in muscle protein synthesis (Emery et al. 1984; Claeys et al. 1989). In contrast, Reeds et al. (1986) reported only a small transient increase in protein synthesis with rats, but concluded that overall the major effect was a reduction in the rate of muscle protein breakdown. This reduction in muscle protein breakdown has also been observed in ruminants (Borohov et al. 1987; Dawson et al. 1988). The cause of this reduced protein catabolism can at present only be a matter of conjecture. One possible explanation lies in the changes in the activity of the calcium-activated neutral protease (calpain; $E C$ 3.4.22.17) system seen in the muscle of treated sheep (Higgins et al. 1988). As illustrated in Table 1 there is a marked increase in the activity of the natural inhibitor of the calpains, calpastatin. However, caution should be exercised in relying too strongly on this explanation since there is evidence that the main role of the calpain system in the cell is associated with degradation of hormone 
Table 1. Effect of dietary restriction or clenbuterol treatment $(2 \mathrm{mg} / \mathrm{kg}$ diet $)$ on calpains I and II (EC 3.4.22.17) and calpastatin activity in sheep Longissimus dorsi muscle*

(Mean values with no. of animals in parentheses)

\begin{tabular}{|c|c|c|c|c|}
\hline Dietary treatment ... & $\begin{array}{l}\text { Control } \\
\text { (6) }\end{array}$ & $\begin{array}{l}\text { Restricted } \\
\text { (4) }\end{array}$ & $\begin{array}{l}\text { Clenbuterol } \\
\text { (6) }\end{array}$ & $\begin{array}{c}\text { Pooled } \\
\text { SED (df 12) }\end{array}$ \\
\hline Average daily wt gain $(\mathrm{kg})$ & $0 \cdot 347$ & 0.048 & $0 \cdot 360$ & 0.037 \\
\hline $\begin{array}{l}\text { Longissimus dorsi wet } \\
\text { wt (g) }\end{array}$ & 635 & 377 & 788 & 53 \\
\hline $\begin{array}{l}\text { Calpastatin (units } / \mathrm{kg} \\
\text { muscle) }\end{array}$ & 2740 & 2340 & 5440 & 420 \\
\hline Calpain I (units/kg muscle) & 570 & 430 & 490 & 60 \\
\hline $\begin{array}{l}\text { Calpain II (units/kg } \\
\text { muscle) }\end{array}$ & 1250 & 1500 & 2880 & 250 \\
\hline
\end{tabular}

SED, standard error of difference.

* For details, see Higgins et al. (1988).

receptors rather than structural muscle proteins (Higgins et al. 1988). It would be most interesting to see if the calpain system were modified following trenbolone acetate treatment which also reduces muscle protein breakdown (see p. 460).

The repartitioning effects of beta-agonists are reported to occur with both adequateand restricted-feeding conditions (Kim et al. 1987). Their effects in enhancing growth rate, however, appear to be variable (Williams, 1987), but findings obtained from this laboratory have indicated that in young steers fed on a high-quality diet (dried grass-barley $(0 \cdot 7: 0 \cdot 3, w / w))$, inclusion of cimaterol $(1.5 \mathrm{mg} / \mathrm{kg})$ can increase growth rate by $>30 \%$ (from $0.86 \mathrm{~kg} / \mathrm{d}$ to $1.13 \mathrm{~kg} / \mathrm{d} ; \mathrm{J}$. M. Dawson, unpublished results).

At the time of writing, beta-agonists have not been approved for use as animal feed additives within the EEC.

\section{OTHER METHODS OF REDUCING THE FAT CONTENT OF THE CARCASS}

As implied previously, the use of the immune response may turn out to be an acceptable method of enhancing the lean deposition and growth rate of animals. Flint et al. (1986) demonstrated that antibodies raised to adipocyte plasma membranes reduce the body fat. Passive immunization against cholecystokinin-8 (CCK-8) increased the feed intake of lean Zucker rats which resulted in an increased growth rate (McLaughlin et al. 1985). Recently active immunization against CCK -8 has been reported to reduce the fat content of sheep carcasses with no significant effect on total body weight gain (Trout et al. 1989).

The use of enhanced concentrations of some natural metabolites in the diet may not be viewed by the public with as much suspicion as the use of hormones or the injections needed for most immunization procedures. One such treatment is the inclusion of dihydroxyacetone and pyruvic acid in the diet which has been reported to reduce the fat content of rats (Stanko et al. 1983) and pigs (Newman et al. 1987).

\section{TRANSGENIC ANIMALS}

Several reports have appeared describing the effects of increasing the copy number of the growth hormone gene in farm livestock. Unfortunately many of the animals have not 
been suitable, or produced in sufficient numbers, for meaningful nutritional studies let alone available for carcass dissection. Evidence available does, however, indicate that many of the responses seen on incorporating extra copies of growth hormone genes into the genome are similar to those observed with exogenously applied growth hormone, including the failure to see an enhanced growth rate unless the animal is adequately fed (Campbell, 1988). Now that transgenesis of farm livestock is a reality, further work is required not only to perfect the control of the expression of the inserted gene(s), but also into the control of the growth process itself. Without a detailed knowledge of these processes it will be very difficult to select which genes are suitable candidates for manipulation.

\section{CONCLUSIONS}

A wide range of techniques are now known to be effective in enhancing the growth rate and extent of lean deposition in animals, but in most cases increases in weight gain are only seen in well-fed animals. Repartitioning of fat and lean, however, can be observed in animals on a lower plane of nutrition. The application of most if not all the techniques discussed previously, at least to the European livestock industry, is currently being constrained both by legislation and by a vocal sector of public opinion. This antagonism is often overriding scientifically sound evidence on the safety of the techniques to the animal, to the consumer of the meat, to those producing the materials and to those involved in the husbandry of the treated animals.

\section{REFERENCES}

Baile, C. A. \& Buonomo, E. C. (1987). Growth hormone-releasing factor. Effects on pituitary function, growth and lactation. Journal of Dairy Science 70, 467-473.

Bass, J. J., Gluckman, P. D., Fairclough, R. J., Peterson, A. J., Davis, S. R. \& Carter, W. O. (1987). Effect of nutrition and immunisation against somatostatin on growth and insulin-like growth factors in sheef. Journal of Endocrinology 112, 27-31.

Borohov, O., Buttery, P. J., Correia, J. H. R. D. \& Soar, J. B. (1987). The effect of the $\beta 2$-adrenergic agonist clenbuterol implantation with oestradiol plus trenbolone acetate on protein metabolism in wether lambs. British Journal of Nutrition 57, 99-107.

Breier, B. H., Gluckman. P. D. \& Bass, J. J. (1988a). The somatotrophic axis in young steers: influence of nutritional status and oestradiol-17ß on high and low-affinity somatotrophic binding sites. Journal of Endocrinology 116, 169-177.

Breier, B. H., Gluckman, P. D. \& Bass, J. J. (1988b). Influence of nutritional status and oestradiol $17 \beta$ on plasma growth hormone, insulin-like growth factors -1 and -11 and the response to exogenous growth hormone in young steers. Journal of Endocrinology 118, 243-250.

Buttery, P. J. \& Sinnett-Smith, P. A. (1982). Mode of action of anabolic agents, with special reference to their effects on protein metabolism - some speculations. In Manipulation of Growth in Farm Animals, pp. 211-228 [J. F. Roche and D. O'Callaghan, editors]. Boston: Martinus Nijhoff.

Campbell, R. G. (1988). Nutritional constraints to lean tissue accretion in farm animals. Nutrition Research Reviews 1, 233-253

Claeys, M. C., Mulvaney, D. R., McCarthy, F. D., Gore, M. T. . Marple, D. N. \& Sartin, J. L. (1989). Skeletal muscle protein synthesis and growth hormone accretion in young lambs treated with clenbuterol. Journal of Animal Science 67, 2245-2254.

Coleman, M. E., Ekeren, P. A. \& Smith. S. B. (1988). Lipid synthesis and adipocyte growth in adipose tissue from sheep chronically fed a beta-adrenergic agent. Journal of Animal Science 66. 372-378.

Dawson, J. M., Buttery, P. J., Beever, D. E.. Gill, M., Lammiman, M. J., Soar, J. B. \& Essex, C. (1988). Rates of muscle protein synthesis in silage fed steers with manipulated carcass composition. In Proceedings of the 5th International Symposium on Protein Metabolism. European Association of Animal Production Publication no. 35. pp. 52-53. 
Dinusson, W. E., Andrews, F. N. \& Beeson, W. M. (1950). The effects of stilbestrol, testosterone and thyroid alterations and spaying on growth and fattening of becf heifers. Journal of Animal Science 9, 321-330.

Elsasser, T. H., Rumsey, T. S. \& Hammond. A. C. (1989). Influence of diet on basal and growth hormone stimulated plasma concentrations of IGF-1 in beef cattle. Journal of Animal Science 67, 128-141.

Emery, P. W., Rothwell, N. J., Stock, M. J. \& Winter. P. D. (1984). Chronic effects of $\beta 2$ adrenergic agonists on body composition and protein synthesis in the rat. Bioscience Reports 4, 83-91.

Enright, W. J. (1989). Effects of administration of somatotropin on growth, feed efficiency and carcass composition of ruminants, a review. In The Use of Somatotropin in Livestock Production. pp. 132-158 [K. Sejrsen, M. Vestergaard and A. Neiman-Sorensen, editors]. London: Elsevier Applied Science.

Fadalla, A. M., Spencer, G. S. G. \& Lister, D. (1985). Passive immunisation against somatostatin and marker retention time in lambs. Journal of Animal Science 61, 234-236.

Flint, D. J., Coggrave, H., Futter, C. E., Gardner, M. J. \& Clarke, T. J. (1986). Stimulating and cytotoxic effects of an antiserum to adipocyte plasma membranes on adipose tissue metabolism in vitro and in vivo. International Journal of Obesity 10, 69-77.

Galbraith, H., Scaife, J., Paterson, G. F. M. \& Hunter, E. A. (1983). Effect of trenbolone acetate combined with oestradiol-17 $\beta$ on the response of steers to changes in dictary protein. Journal of Agricultural Science, Cambridge 101, 249-252.

Gill, M., Beever, D. E., Buttery, P. J., England, P., Gibb, M. J. \& Baker, R. D. (1987). The effect of oestradiol-17 $\beta$ implantation on the response in voluntary intake, liveweight gain and body composition to fishmeal supplementation of silage offered. Journal of Agricultural Science, Cambridge 108, 9-16.

Hanrahan, J. P. (1987). Beta Agonists and Their Effects on Animal Growth and Carcass Composition. London: Elsevier Applied Science.

Heitzman. R. J., Carter, A., Dixon. S. N., Harwood, D. J. \& Phillips, M. (1984). In Recent Studies on Pharmokinetics and Residues of Anabolic Agents in Beef Cattle and Other Farm Animals, pp. 1-16 [J. F. Roche and D. O'Callaghan, editors]. Boston: Martinus Nijhoff.

Higgins. J. A., Lasslett. Y. V., Bardsley, R. G. \& Buttery, P. J. (1988). The relation between dictary restriction or clenbuterol (a selective $\beta 2$ agonist) treatment on muscle growth and calpain proteinase ( $E C$ 3.4.22.17) and calpastatin activities in lambs. British Journal of Nutrition 60, 645-652.

Holder. A. T. \& Aston. R. (1989). Antigen-Antibody complexes that enhance growth. In Biotechnology in Growth Regulation, pp. 167-178 [R. B. Heap, C. G. Prosser and G. E. Lamming, editors]. London: Butterworths.

Hunter, R. A. \& Vercoe, J. E. (1987). Reduction of energy requirements of steers fed on low-quality-roughage diets using trenbolone acetate. British Journal of Nutrition 58, 477-483.

Kim, Y. S. Lec, Y. B., Ashmore, C. R. \& Dalrymple, R. H. (1987). Effect of cimaterol on skeletal muscle characteristics of lambs. Journal of Animal Science 65, Suppl. 1, 278 Abstr.

Lamming, G. E., Ballarina, G., Baulieu, E. E., Brookes, P.. Elias, P. S., Ferrando, R., Galli, C. L., Heitzman, R. J., Hoffman, B., Kang, H., Mayer, H. H. D., Michel, G., Poulsen, E., Rico, A., Van Leevwen, E. R. \& White, D. S. (1987). Scientific report on anabolic agents in animal production. Veterinary Record 121, 389-392.

McLaughlin, G. L., Baile, C. A. \& Buonomo, E. C. (1985). Effect of CCK antibodies on food intake and weight gain in Zucker rats. Physiology and Behaviour 34, 543-548.

Martinez, J. A., Buttery, P. J. \& Pearson, J. T. (1984). The mode of action of anabolic agents, the effects of testosterone on growth rates and muscle protein metabolism in female rats. British Journal of Nutrition 54, $515-521$.

Mersmann, H. J., Hu, C. Y., Pond, W. G., Rule, D. C., Novakofski, J. E. \& Smjth, S. B. (1989). Growth and adipose tissue metabolism in young pigs fed cimaterol with adequate and low dictary protein. Journal of Animal Science 64, 1384-1394.

Millard, W. J. (1989). Central regulation of growth hormone secretion. In Animal Growth Regulation, pp. 237-255 [D. R. Campion, G. J. Hausman and R. J. Martin, editors]. New York: Plenum Press.

Newbold, J. R., Garnsworthy, P. C., Buttery, P. J., Cole, D. J. A. \& Haresign, W. (1988). Responses of British Friesian steers with or without implants of oestradiol-17 $\beta$ to undegradable dietary protein. Animal Production 46. 181-193.

Newman, C. W., Newman, R. K. \& Stanko, R. T. (1987). Reduction of body fat in swine with ingestion of dihydroxyacetone (DHA) and pyruvate (P). Federation Proceedings 46, 1178.

Patel, Y. C. (1987). Somatostatin. In Growth Hormone, Growth Factors and Acromegaly, pp. 21-36 [D. K. Ludecke and G. Tolis, editors]. New York: Raven Press. 
Pell, J. M. (1989). Growth promoting properties of recombinant growth hormone. In Biotechnology in Growth Regulation, pp. 85-96 [R. B. Heap, C. G. Prossier and G. E. Lamming, editors]. London: Butterworths.

Pell, J. M., Gill, M. \& Beever, D. E. (1989). Variability of responsiveness to growth hormone in ruminants: nutrient interactions. In The Use of Somatostatin in Livestock Production, pp. 286-287 [K. Sejrsen, M. Vestergaard and A. Neiman-Sorensen, editors]. London: Elsevier Applied Science.

Peters, J. P. (1986). Consequences of accelerated gain and growth hormone administration for lipid metabolism in growing beef steers. Journal of Nutrition 116, 2490-2503.

Reeds, P. J., Hay, S. M., Dorwood, P. M. \& Palmer, R. M. (1986). Stimulation of muscle growth by clenbuterol: lack of effect on muscle protein biosynthesis. British Journal of Nutrition 56, 249-258.

Sinnett-Smith, P. A., Dumelow, N. W. \& Buttery. P. J. (1983). The effects of trenbolone acetate and zeranol on protein metabolism in male castrate and female lambs. British Journal of Nutrition 50, 225-239.

Spencer, G. S. G., Garsson, G. J. \& Hart, I. G. (1983). A novel approach to growth promotion using autoimmunisation against somatostatin. II. Effects on appetite, carcass composition and food utilization in lambs. Livestock Production Science 10, 469-477.

Stanko, R. T., King, D. \& Adibi, S. A. (1983). Inhibition of lipid synthesis and stimulation of energy expenditure by addition of pyruvate, dehydroxy acetone and riboflavin in the diet. Clinical Research 31, 526A.

Trout, W. E., Pekas, J. C. \& Schanbachar, B. D. (1989). Immune, growth and carcass responses of ram lambs to active immunisation against desulphated cholecystokinin (CCK-8). Journal of Animal Science 67, 2709-2714.

Vernon, B. G. \& Buttery, P. J. (1978). The effect of trenbolone acetate with time on the various responses of protein synthesis of the rat. British Journal of Nutrition 40, 563-572.

Williams, P. E. V. (1987). The use of $\beta$-agonists as a means of altering body composition in livestock species. Nutrition Abstracts Review B 57, 453-464. 